\title{
Cytotoxic activity screening of ethyl acetate fungal extracts derived from the marine sponge Neopetrosia chaliniformisAR-01
}

\author{
Muh. Ade Artasasta ${ }^{1}$, Yanwirasti $^{2}$, Akmal Djamaan $^{1}$, Dian Handayani ${ }^{1}{ }^{*}$ \\ ${ }^{1}$ Laboratory of Sumatran Biota, Faculty of Pharmacy, Andalas University, Padang, Indonesia. \\ ${ }^{2}$ Faculty of Medicine, Andalas University, Padang, Indonesia.
}

\author{
ARTICLE INFO \\ Article history: \\ Received on: 08/10/2017 \\ Accepted on: 26/11/2017 \\ Available online: 30/12/2017

\section{Key words:} \\ $N$. chaliniformis, Sponge- \\ derived fungus, Aspergillus \\ nomius, Molecular \\ Characterization, Cytotoxic \\ activity.
}

\begin{abstract}
This research explored the potential of fungi derived from the marine sponge Neopetrosia chaliniformis as producers of cytotoxic compounds. Fungi derived from $N$. chaliniformis were isolated by cultivating on Saboroud Dextrose Agar (SDA) and purified by streak plating. The pure isolated fungi were cultivated using rice as media at $25-27{ }^{\circ} \mathrm{C}$ for $4-8$ weeks and extracted using ethyl acetate solvent. The ethyl acetate extracts were tested for cytotoxicity using an MTT assay against colon cancer cells (WiDr) and normal cells (VERO). The fungal isolates which have the greatest cytotoxic activity were identified based on morphological and molecular characterization. Thirteen isolates of the fungus were obtained from $N$. chaliniformis. Six fungi isolates labeled $\mathrm{NC} 01, \mathrm{NC} 02, \mathrm{NC} 03, \mathrm{NC} 06, \mathrm{NC} 07$, and $\mathrm{NC} 09$ were found to be cytotoxically active with percentage of viability against WiDr colon cancer cells of 12.1, -2.43, 29.02, 70.31, 14.04, and 46.04, respectively. However, only NC06 isolate that was identified as Aspergillus nomius with a homology percentage of $99 \%$ based on molecular characterization using 18S rRNA primer showed non-cytotoxic activity against normal Vero cells with percentage of viability of $113.99 \%$.
\end{abstract}

\section{INTRODUCTION}

Marine sponges are hosts to various bacteria and fungi. (Hentchel et al., 2006; Wang, 2006). But the type of relationship and ecological function of these microorganisms in the sponges remain unclear (Wiese et al., 2011). However, some, especially fungi, are known to produce potentially bioactive compounds that could be used to combat cancer and pathogenic microbial infections (Wiese et al., 2011; Bhadury et al., 2006; Vasanthabharathi and Jayalakshmi, 2011). The marine sponge Neopetrosia chaliniformis is an endemic sponge found along the Indonesian coastline whose medicinal potential is only beginning to be investigated. In our previous research, we isolated 13 fungi

\section{* Corresponding Author}

Dian Handayani, Faculty of Pharmacy, University of Andalas, Padang, Indonesia. E-mail: dianh_17 @ yahoo.com, Tel.: +62 8126785517, Fax: +6275177705. derived from $N$. chaliniformis and over three-quarters of these produced cytotoxic isolates with $\mathrm{LC}_{50}<100 \mathrm{ppm}$ using a Brine Shrimp Lethality Test. We also reported on fungi isolates that showed antibacterial activity against B. subtilis, S. epidermidis, S. typhosa and E. coli (Handayani and Artasasta, 2017). This present research is a continuation of the effort to identify bioactive compounds from marine sponge-derived fungi.

\section{MATERIALS AND METHODS}

\section{Sponge material, isolation, cultivation and extraction of Secondary Metabolites from Fungi Isolates associated with marine sponges}

The sponge material which was used and the stages of the research method for isolation and cultivation of fungi were carried out as in our previous study (Handayani dan Artasasta, 2017). 


\section{MTT Assay \\ Sample Screening}

Two cell lines, WiDr as a colon adenocarcinoma cell line, and Vero as normal cell line were prepared for cytotoxic assay using MTT. All cell lines were obtained from Laboratory of Parasitology at Gajah Mada University, Yogyakarta, Indonesia. WiDR was cultured in RPMI 1650 and Vero was cultured in M199 Medium. All cells were subcultured after mild trypsinization with trypsin-EDTA (Sigma-Aldrich, USA), and then the cell number and viability were determined. The cells were seeded onto 96-well plates at a density of $6 \times 10^{3}$ cells/well in $100 \mu \mathrm{L}$ medium and incubated overnight. All media were supplemented with $10 \%$ fetal bovine serum (Gibco) and streptomycin and penicillin (2\%, Sigma-Aldrich, USA). The cell line were kept at $37^{\circ} \mathrm{C}, 98 \%$ relative humidity with $5 \% \mathrm{CO}_{2}$ atmosphere.

A stock solution was prepared by dissolving the samples in DMSO at 100,000 ppm. Cells that had been incubated 24 hours were divided into groups; treatment, positive control, cell control and media control (blank). The medium was removed and the cells washed using $100 \mu \mathrm{L}$ sterile PBS in each well. Then, $100 \mu \mathrm{L}$ of each material (extract) at concentration of 100 ppm was added to each well. Doxorubicin was used as the positive control. Each extract was incubated for 24 hours at $37^{\circ} \mathrm{C}, 5 \% \mathrm{CO}_{2}$ then mixed throughout the medium and washed using sterile PBS. Then 100 $\mathrm{mL}$ of MTT $(5 \mathrm{mg} / \mathrm{ml})$ was added to each well followed by a 4hour incubation at $37^{\circ} \mathrm{C}, 5 \% \mathrm{CO}_{2} .100 \mu \mathrm{L}$ of $10 \%$ SDS was added to each well to dissolve the formazan crystals formed followed by overnight incubation at room temperature. The plates were then read by an ELISA reader at $540 \mathrm{~nm}$ (Permanasari et al., 2016). The aim of this screening was to identify the presence of cytotoxic activity.

\section{Cytotoxic Screening}

The cytotoxicity on WiDr cells of the EtOAc fungal extracts derived was determined by the MTT assay. $5 \times 10^{3} /$ well cells were plated with $100 \mu \mathrm{L}$ of medium/well in 96-well plates. After overnight incubation in a humidified atmosphere with $5 \%$ $\mathrm{CO}_{2}$ at $37{ }^{\circ} \mathrm{C}$, the fungal extract was added in concentrations of $100 \mathrm{ppm}$. $100 \mu \mathrm{L}$ of $0.5 \mathrm{mg} / \mathrm{mL}$ MTT ( $\mathrm{pH} 4.7$ ) was then added to each well and cultivated for another 4 hours. The reaction was stopped by $100 \mu \mathrm{L}$ SDS (10\%) in $\mathrm{HCl} 0.01 \mathrm{~N}$ per well. After overnight incubation, the absorbance at $595 \mathrm{~nm}$ was measured with an ELISA reader (Bio-Rad), using wells without cells as blanks. All experiments were performed in triplicate. Doxorubicin was used as a positive control. The effect of each fungal extract on the proliferation of colon cancer cells was expressed as the percent viability.

\section{Molecular Identification \\ DNA Extraction}

DNA extraction was conducted by following the method of Saitoh et al. (2006). Mycelia of fungal isolate were excised with a toothpick from a 4-6 day-old culture plate and transferred to a microtube with $500 \mu \mathrm{L}$ of lysis buffer. The mycelia were dispersed in the buffer with a toothpick and incubated for $10 \mathrm{~min}$ at room temperature. The mixture was centrifuged at $18000 \mathrm{rpm}$ for $5 \mathrm{~min}$ at $4^{\circ} \mathrm{C}$. The supernatant was transferred to a fresh micro-tube and mixed with $750 \mu \mathrm{L}$ of ethanol by inverting the tube, the DNA was precipitated by centrifugation at $18000 \mathrm{rpm}$ for $2 \mathrm{~min}$ at $4{ }^{\circ} \mathrm{C}$. The DNA pellet was dried than dissolved in $50 \mu \mathrm{L}$ of TE buffer $\mathrm{pH}$ 8.0.

\section{PCR Amplification and Sequencing of 18S rRNA-encoding gene}

The PCR mixture $(50 \mu \mathrm{L})$ containing $1 \mu \mathrm{L}$ of the DNA template, $20 \mu \mathrm{L} \mathrm{dH_{2 }} \mathrm{O}, 25 \mu \mathrm{L}$ PCR master mix, $2 \mu \mathrm{L}$ primer $18 \mathrm{~F}$ (5' -ATC TGG TTG ATC CTG CCA GT-3') and $2 \mu \mathrm{L}$ primer $18 \mathrm{R}$ (5' -GAT CCT GCA GGT TCA CC-3'). Amplification reactions were performed in a Hybaid Omnigene thermal cycler. An initial denaturation for 2 min at $94{ }^{\circ} \mathrm{C}$ was followed by 30 cycles of 15 sec at $94{ }^{\circ} \mathrm{C}, 30 \mathrm{sec}$ at $60{ }^{\circ} \mathrm{C}$ and $1.30 \mathrm{~min}$ at $68{ }^{\circ} \mathrm{C}$ and final extension of $10 \mathrm{~min}$ at $78{ }^{\circ} \mathrm{C}$.

PCR products were sequenced in First Base, Malaysia. The sequences were analyzed by the BLASTN program on NCBI. Analysis of phylogenetic trees was constructed using neighborjoining tree method with a bootstrap value of 1000 replication by using MEGA 7.0 software (Tamura et al., 2016).

\section{RESULTS AND DISCUSSION}

Screening of cytotoxic activity used an MTT assay to measure cytotoxicity to WiDr colon cancer cells compared to VERO normal cells. The optimally performing extract was classified by its toxicity to cancer cells while being non-toxic to normal cells. The $100 \mathrm{ppm}$ EtOAc extract of the NC06 isolate was the most selectively cytotoxic extract on WiDr colon cancer cells and VERO normal cells with percentage of viability being $70.31 \%$ and $113.99 \%$, respectively (Table 1). The NC06 isolate was then identified using molecular characterization by partial sequence analysis of the $18 \mathrm{~S}$ rRNA gene.

Table 1: The cytotoxic activity of EtOAc fungal extract $100 \mathrm{ppm}$ derived from marine sponge $N$. chaliniformis by using MTT method.

\begin{tabular}{|c|c|c|c|}
\hline \multirow[t]{2}{*}{ No } & \multirow{2}{*}{$\begin{array}{c}\text { Fungal Isolates } \\
\text { Code }\end{array}$} & \multicolumn{2}{|c|}{ Percentage of viability (\%) } \\
\hline & & WiDr & VERO \\
\hline 1 & NC01 & 12.11 & -5.57 \\
\hline 2 & $\mathrm{NC} 02$ & -2.43 & 26.56 \\
\hline 3 & $\mathrm{NC} 03$ & 29.02 & -1.73 \\
\hline 4 & $\mathrm{NC} 04$ & - & - \\
\hline 5 & $\mathrm{NC} 05$ & 110.44 & -1.58 \\
\hline 6 & NC06 & 70.31 & 113.99 \\
\hline 7 & $\mathrm{NC} 07$ & 14.04 & 21.14 \\
\hline 8 & NC08 & 95.52 & 128.14 \\
\hline 9 & NC09 & 46.04 & 19.48 \\
\hline 10 & $\mathrm{NC} 10$ & 106.85 & 137.77 \\
\hline 11 & $\mathrm{NC} 11$ & 109.61 & 136.94 \\
\hline 12 & $\mathrm{NC} 12$ & - & - \\
\hline 13 & $\mathrm{NC} 13$ & - & - \\
\hline Positive Control & Doxorubicin & 16.42 & 96.68 \\
\hline
\end{tabular}

The 18S rRNA-encoding gene was amplified using PCR using universal primers 18F (5 '-ATC TGG TTG CTC CCA GT3 ') and 18R (5 '-GAT CCT GCA GCA TCA CC-3'). DNA bands of 1690 bp were obtained (Figure 1). A BLAST search in NCBI- 
GenBank showed that the NC06 isolate had a maximum identity of $99 \%$ with Aspergiilus nomius.

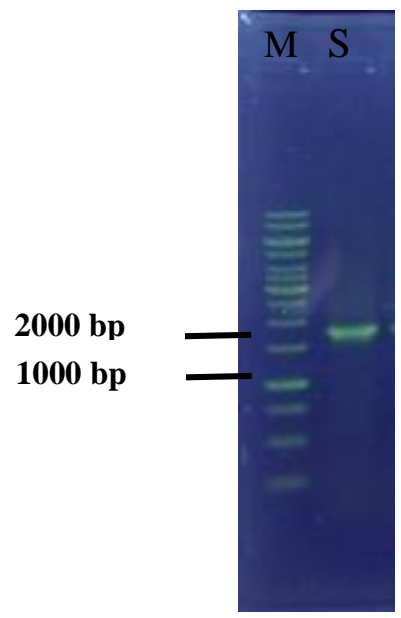

Fig. 1: PCR product of 18S rRNA gene from NC06 isolate derived from $N$. chaliniformis. There is a $1690 \mathrm{bp}$ band from the sample and the marker is $1 \mathrm{~kb}$.
The phylogenetic tree was constructed using a neighborjoining method with a bootstrap value of 1000 . The result of analysis showed that tree formation consists of two clades. Clade 1 was a group of Aspergillus and clade 2 was a group of Penicillium. NC06 isolate was on clade 1 confirming its identity as Aspergillus nomius (Figure 2).

Cytotoxic screening is conducted using a cancer cell line to determine the specific sensitivity of the effect of the bioactive compound. In this study, cytotoxic screening was performed using a WiDr colon cancer cell line and the cytotoxic effect compared with normal VERO cells. The WiDr colon cancer cell line was chosen because it can be cultured easily and repeatedly for cytotoxic testing (Rohmah et al., 2013).

In this research, we used an MTT assay. This is a colorimetric method, in which the MTT reagent is a tetrazolium salt that can be broken down by succinate-tetrazolium reductase, a mitochondrial enzyme, to produce purple formazan crystals. The absorbance of these crystals can then be measured using an ELISA reader (Doyle and Griffith, 2000; Berrigde et al., 1993).

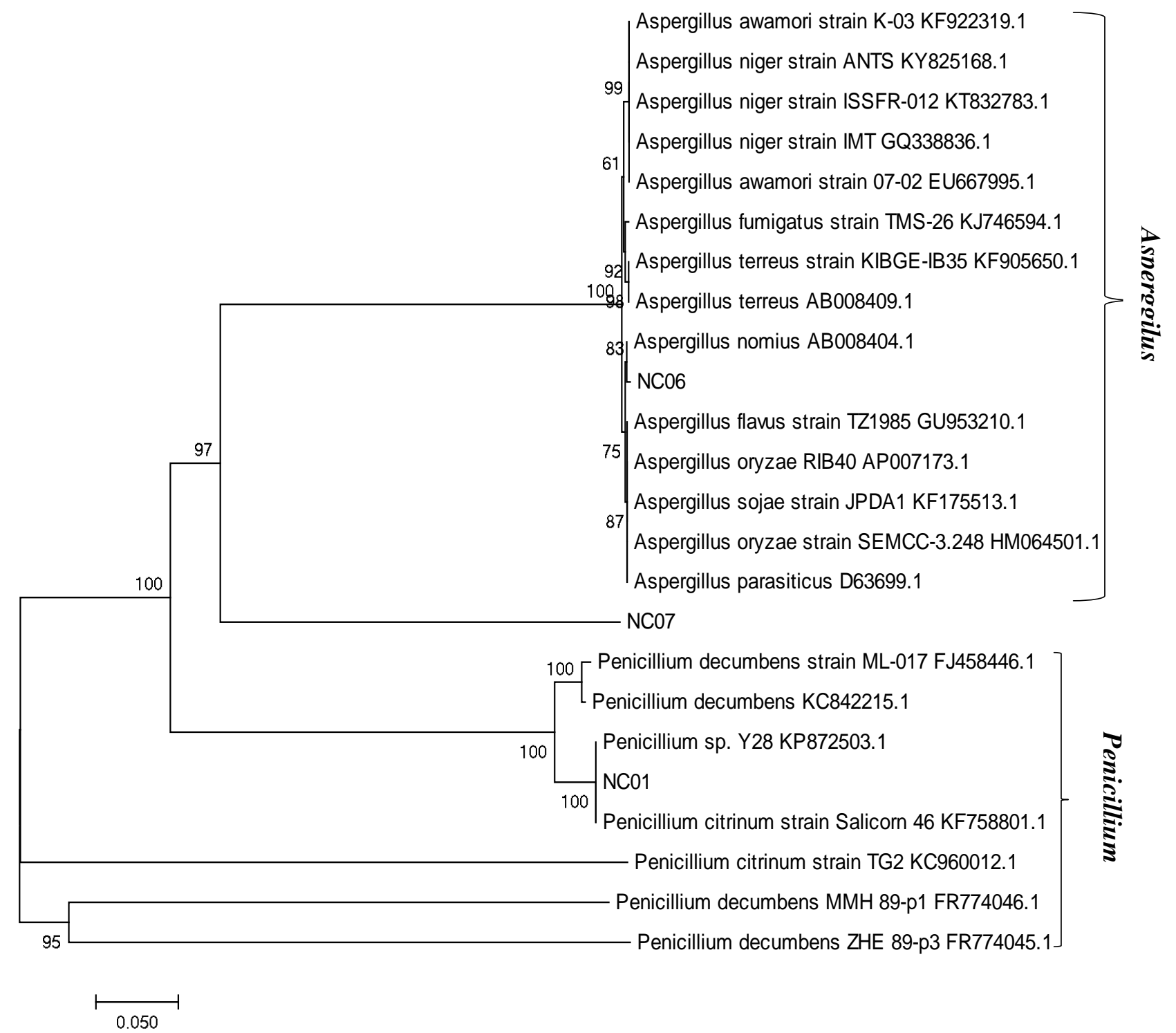

Fig. 2: The phylogenetic tree by using neighbour-joining method of $18 \mathrm{~S}$ rRNA gene sequence from some of fungi isolate derived N.chaliniformis and some strain of Aspergillus and Penicillium. The scale bar indicates a 0.05 substitution nucleotide position. 
The optimally performing extract was classified by its toxicity to cancer cells while being non-toxic to normal cells. The 100 ppm EtOAc extract of the NC06 isolate was the most selectively cytotoxic extract on WiDr colon cancer cells and VERO normal cells with percentage of viability being $70.31 \%$ and $113.99 \%$, respectively. Gomes, et el., (2015) revealed that a cytotoxic compound can be a potential anticancer agent when it shows selectivity between normal and cancer cell lines, exhibit activity against multidrug-resistance (MDR), and demonstrates a cell death mechanism through inhibiting non-apoptosis.

Based on the reconstruction of the phylogeny tree in Figure 2. NC06 isolate shows 99\% homology with Aspergillus nomus. Little is known about the effects of bioactive compounds from A. nomius on WiDr colon cancer cells. However potential anti-cancer activity against human colon cancer cell lines has been demonstrated. For example, Lee et al., (2010) showed some compounds from Aspergillus versicolor derived from Petrosia sp had $\mathrm{IC}_{50}$ against HCT15 colon cancer cell line below 30 $\mu \mathrm{g} / \mathrm{mL}$. Chol et al., (2010) found that diketopiperazine disulfides produced by the marine fungus Aspergillus sp KMD 901 had potential to induce apoptosis on HCT116 colon cancer line. Avrainvillamide derived from marine Aspergillus sp. CNS358 has a dose-dependent cytotoxic effect against human colon cancer cell HCT116 with $\mathrm{IC}_{50}$ of $2.0 \mu \mathrm{g} / \mathrm{mL}$ (Fenical et al., 2000). Aspergillus sp. derived from marine sediment was found to contain the peptide aspergillamide, that had a mild cytotoxic effect on human colon carcinoma HCT-116 cell with $\mathrm{IC}_{50}$ of $16 \mu \mathrm{g} / \mathrm{mL}$ (Toske et al., 1998).

The secondary metabolites that have been isolated from Aspergillus nomius are nominine, aspernomine, 14hydroxipaspalinine, and 14-(N, N-dimethyl-L-valyloxy) paspalinine. These compounds are Indole alkaloids derived from cyclic dipeptides which have bioactivity as insecticides (James and Rinderknecht, 1989; Staub et al., 1992; Staub et al., 1993). However, one strain of fungus can produce diverse secondary metabolites depending on growth media and source. (Bode et al., 2002). Therefore, the NC06 isolate from Neopetrosia chaliniformis that showed similarity to Aspergillus nomius may produce other secondary metabolites just as the fungus Dothideomyceta $s p$. CR17 produced diverse compounds in different media (Senadeera et al., 2012). When cultivated in PDB medium prepared from fresh potato tubers, CR17 produced azaphilone derivatives such as dothideomycetones A, B and dothideomycetide A with a tricyclic polyketide but upon cultivation in PDB medium prepared from a commercial potato powder it produced calbistrin F, G and $\mathrm{H}$.

\section{CONCLUSION}

Marine derived fungus $\mathrm{NC06}$ from sponge $N$. chaliniformis AR-01 showed the most selective cytotoxicity against WiDr cell line compared to the Vero cell line. Molecular characterization indicated that this NC06 fungus was Aspergillus nomius. Further research needs to be conducted to identify the cytotoxic compounds produced by the fungus.

\section{CONFLICT OF INTERESTS}

Declared none

\section{ACKNOWLEDGEMENT}

Financial support and sponsorship: This research was funded by The Ministry of Research and Technology, Indonesia in project "Master Program of Education Leading to Doctoral Degree for Excellent Graduate (PMDSU) Research, 059/SP2H/LT/DRPM/IV/2017.”

Conflict of Interests: There are no conflicts of interest.

\section{REFERENCES}

Berridge MV, Tan AS. Characterization of the cellular reduction of 3-(4,5-dimethylthiazol 2-yl)-2,5-diphenyltetrazolium bromide (MTT): subcellular localization, substrate dependence, and involvement of mitochondrial electron transport in MTT reduction. Arch Biochem Biophys 1993;303(2):474-82.

Bhadury P, Mohammad BT, and Wright PC. The current status of natural products from marine fungi and their potential as anti-infective agents. J. Ind. Microbiol. Biotechnol, 2006; 33:325-337.

Brigitte G. Kompendium der Medizinschen Mykologi. 1980, Berlin-Hamburg. Verlag Paul Parey.

Bode HB, Betha B, Hofs R, and Zeeck A. Big Effects from Small Changes: Possible Ways to Explore Nature's Chemical Diversity. Chem BioChem, 2002; 3: 619-627.

Chol EJ, Park JS, Kim YJ, Jung JH, Lee JK, Kwon HC, and Yang HO. Apoptosis-inducing effect of diketopiperazine disulfides produced by Aspergillus sp. KMD 901 isolated from marine sediment on HCT116 colon cancer cell line. Journal of Applied Microbiology, 2010; 110: 304-313.

Doyle A, Griffths JB. 2000. Cell and tissue culture for medical research. New York: John Willey and Sons Ltd.

Fenical W, Jensen PR, and Cheng XC. Avrainvillamide, a cytotoxic marine natural products, and derivatives thereof. 2000. US1999027489919990323.

Gloer JB, and Rinderknecht. Nominine: A New Insecticidal Indole Diterpene from the Sclerotia of Aspergillus nomius. J. Org. Chem, 1989; 54: 2530-2532.

Gomes NGM, Lefranc F, Kijjoa A and Kiss R. Can Some Marine-Derived Fungal Metabolites Become Actual Anticancer Agents? Marine Drugs, 2015; 13:3950-3991.

Handayani D, Artasasta MA. Antibacterial and cytotoxic activities screening of symbiotic fungi extract isolated from marine sponge Neopetrosia chaliniformis AR-01. JAPS, 2017; 7(5): 66-69.

Hentschel U, Usher KM, and Taylor MW. Marine sponge as microbial fermenters. FEMS Microbiology Ecology, 2006; 55(2): 167177.

Kjer J, Debbab A, Aly AH, dan Proksch, P. Methods for isolation of marine-derived endophytic fungi and their bioactive secondary products. Nature Protocols, 2010; 5:479-490.

Lee YM, Li H, Hong J, Cho HY, Bae KS, Kim MA, Kim DK, and Jung JH. Bioactive Metabolites from the Sponge-Derived Fungus Aspergillus versicolor. Archives of Pharmacal Research, 2010; 33:231235.

Permanasari P, Hertiani T, Yuswanto A. Immunomodulatory Effect of Massoia Bark Extract and The Cytotoxicity Activiy Against 
Fibroblast and Vero Cells in Vitro. International Journal of Pharmaceutical and Clinical Research, 2016; 8(5) Suppl:326-330.

Rohmah AL, Amalia F, Rivanti E, Putri DDP, Nurulita NA. Cytotoxic Activity and Apoptosis Induction of Ethanolic Extract of Pericarps of Mangosteen (Garcinia mangostana Linn.) on WiDr cells and Interaction Study of Alpha-mangosteen to IKK and VEGF Based on Molecular Docking. ISCC, 2013; 4(1): 470-476.

Saitoh KI, Togashi K, Arie T, Teaoka T. A simple method for mini-preparation of fungal DNA. J Gen Plant Pathol, 2006; 72: 348-350.

Senadeera SP, Wiyakrutta S, Mahidol C, Ruchirawat S, Kittako P. A novel tricyclic polyketide and its biosynthetic precursor azaphilone derivatives from the endophytic fungus Dothideomycete $s p$. Org. Biomol. Chem, 2012; 10: 7220-7226.

Staub GM, Gloer JB, Wicklow DT, and Dowd PF. Aspernomine: A Cytotoxic Antiinsectan Metabolite with a Novel Ring System the Sclerotia of Aspergillus nomius. J. Am. Chem, 1992; 114: 1015-1017.

Staub GM, Gloer KB, and Gloer JB. New Paspaline Derivatives With Antiinsectan Activity The Sclerotia of Aspergillus nomius. Tetrahedron Letters, 1993; 34(16): 2569-2572.

Toske SG, Jensen PR, Kauffman CA, and Fenical W. Aspergillamides $\mathrm{A}$ and $\mathrm{B}$ : modified cytotoxic tripeptides produced by a marine fungus of the genus Aspergillus. Tetrahedron, 1998;54: 1345913466.
Wang G. Diversity and biotechnological potential of the sponge-associated microbial consortia, 2006; 33: 545-551.

Wiese J, Ohlendorf B, Blumel M, Schmaljohann R, and Imhoff JF. Phylogenetic Identification of Fungi Isolated from the Marine Sponge Tethya aurantium and Identification on Their Secondary Metabolites. Mar. Drugs, 2011; 9: 561-585.

Vasanthabharathi V, and Jayalakshmi S. Bioactive potential of symbiotic bacteria and fungi from marine sponges. African Journal of Biotechnology, 2011; 11:7500-7511.

\section{How to cite this article:}

Artasasta MA, Yanwirasti, Djamaan A, Handayani S. Cytotoxic activity screening of ethyl acetate fungal extracts derived from the marine sponge Neopetrosia chaliniformis AR-01. J App Pharm Sci, 2017; 7 (12): 174-178. 